\title{
Mutual Assistance among Russian Peasants: Practices of Pomochi and Their Evolution in the Course of Modernisation
}

\section{DAVYDOVA*}

\begin{abstract}
*Irina Davydova - PhD in Sociology, Unaffiliated Scholar, worked at Novosibirsk State University, Manchester University, Newcastle University. Address: Newcastle, Great Britain. E-mail: ira.davydova@gmail.com

Citation: Davydova I. (2018) Mutual Assistance among Russian Peasants: Practices of Pomochi and Their Evolution in the Course of Modernisation. Mir Rossii, vol. 27, no 3, pp. 107-129. DOI: 10.17323/1811-038X-2018-27-3-107-129
\end{abstract}

This paper presents a study of pomochi as an example of the practices of mutual assistance among Russian peasants, and of the transformation of these practices in the course of modernisation. The study relies on various sources, including materials from ethnographic surveys conducted in the nineteenth century, and the archive of life-histories of villagers, recorded in 1991-2 in the Saratov region. The practices of mutual assistance are considered from the methodological position, which derives from works of Winch and Schutz, who emphasised the fundamental distinction between social conceptions, which are constitutive of social life, and sociological concepts, which are tools of sociologists and are constructed according to the rules of their academic discipline. This position assigns a subsidiary role to sociological concepts and theories, suggesting a pragmatic choice of those, and requires heightened sensitivity in the interpretation of data. Accordingly, the practices of mutual assistance have been considered in terms of Sahlins 'typology of reciprocities, as a relic of the ancient communal farming system, in terms of a broadly Marxist approach as a form of production cooperative, and in terms of Chayanov's theory of peasant economy each illuminating particular features of mutual assistance among peasants or certain aspects of peasant life in general. The study has shown how the practices of mutual assistance were an essential feature of the peasant way of life, and traced their gradual disintegration as that way of life was itself falling apart.

Key words: sociological theory, social conceptions, mutual assistance, pomochi, collectivism, modernisation 


\section{Introduction}

Pomochi is a Russian term denoting an occasion of collectively helping a member of the village community to accomplish a particular task in one day, on request and free of charge. On completion of the work, the effort was rewarded with a feast provided by the beneficiary. The custom was of ancient origin and widespread among peasant communities in Imperial Russia. Its decline was due to the increasing monetisation of the rural economy in the early twentieth century, and then due to the collectivisation of agriculture under the Soviet system.

Apart from historical interest, practices of mutual assistance among Russian peasantry have some bearing upon the broader topic of the alleged collectivist character of the Russian culture and people. Russia was a rural country for longer than most other European nations. In 1926 only $18 \%$ of its population lived in towns and cities, by 1979 the share of urban population had increased to 62\%, two thirds of which were first and second generation rural migrants [Rybakovsky 1981, pp. 8-9]. The tendency to idealise the Russian peasant is longstanding. Russian intellectuals of various political convictions were fascinated by the Russian peasant commune (mir, obschina) with its regular repartition of land. For Konstantin Aksakov, a Slavophil, the peasant commune was an embodiment of sobornost 1 [Aksakov 1989, pp. 279-280]; Alexander Herzen, a revolutionary, celebrated the good fortune by which the commune "had survived right into the period that witnesses the rise of Socialism in Europe" [Herzen 1979, p. 190]; Maxim Kovalevsky, one of the founders of sociology, wrote that Russians are "a people who, though rough and rude, yet enjoy the great blessing of being unconscious of the need of securing their individual happiness by a constant struggle and by the pursuit of egoistic ends. [...] The reliance shown by the Russian peasant on the community [...] has certainly developed estimable qualities and has helped to the make the Russian moujik a communist" [Kovalevsky 1891, p. 61]. On the other hand, in the aftermath of the Great October Revolution, Georgy Fedotov did not find much difference between the Russians and the Homo Europaeo-Americanus of the early twentieth century [Fedotov 1938, p. 259].

No sociological research can settle the on-going dispute about the Russian national character because such disagreements involve values. The focus of the study presented in this paper is rather narrow: pomochi as an example of the practices of mutual assistance among Russian peasantry in the late nineteenth-early twentieth century. The objective is to consider these practices as part of the particular way of life and to trace their evolution in the course of modernisation. This is done from a specific methodological position which derives from the intellectual tradition developed outside mainstream sociology. This position makes a principal distinction between social conceptions, which are constitutive of social life and are used by lay members of society, and sociological concepts, which are tools of sociologists and obey the rules of their academic discipline. This position

\footnotetext{
1 Sobornost-spiritual community of many jointly living people [Ozhegov, Shvedova 1992] - a concept introduced by the early Slavophiles. Aksakov explained the idea by analogy with a choir: "commune is a moral choir, and as in a choir an individual voice is not lost but by subjecting to general order is heard in harmony of all other voices, so in a commune a personality is not lost but by refusing exclusivity for the sake of general agreement finds itself in a higher, purer state, in harmony of equally self-refusing personalities [Aksakov 1989, pp. 279-280].
} 
alerts to the limited validity of sociological concepts and requires heightened sensitivity in the interpretation of data.

The data used in the study come from various sources. Rich ethnographic material on pomochi, collected from 71 uyezd $^{2}$ (29 governorates) by the Free Economic Society for Encouragement of Agriculture and Husbandry (1877-1878 survey) and by the Tenishev Ethnographic Bureau (1897-1900) was systematised by Gromyko [Gromyko 1986]. Evidence of the existence of pomochi in the earlier period was found in records of local administrative and criminal proceedings: peasant petitions, sentences passed by peasant communes, volost administration's reports, search records, etc. In such documents pomochi are only mentioned in passing, e.g. "the plaintiff was going home from that pomoch, at night, after 9pm" [Gromyko 1986, p. 32]. Data for the turbulent twentieth century is patchy. For that period the study relies on the ethnographic survey of 1927-8 in Vyatka region [Tikhonitskaya 1934], a publication of life-histories of rural people [Berdinsky 2011], and on the archive of life-histories, recorded in Saratov region in 1991-2 in the framework of Shanin's project of 1991-4. Detailed information about Shanin's project can be found in Vinogradsky [Vinogradsky 1998]. The author of this paper was fortunate to be granted access to this archive and to use it in her $\mathrm{PhD}$ thesis [Davydova 1999].

The paper is structured as follows. Next part explains in some details the methodological position. Part 3 describes the practices of pomochi, drawing on the ethnographical surveys of the late nineteenth century. In part 4 these practices are discussed, relying on the relevant concepts and theories. Thus, the practices of pomochi are considered i) in terms of Sahlins' typology of reciprocities; ii) as a relic of the ancient communal farming system; iii) in terms of a broadly Marxist approach as a form of production cooperative and; iv) in terms of Chayanov's theory of peasant economy. Chayanov's theory does not deal with the practices of mutual assistance as such. But it explains well how peasant family farms operated, which is crucial for understanding of the role mutual assistance in peasant life. Part 5 traces the transformations of the practices of mutual assistance in the course of modernisation, due to the monetisation of the rural economy in the late nineteenth-early twentieth centuries and due to the collectivisation of agriculture. Part 6 concludes the paper.

\section{The methodology}

\section{The nature of social phenomena}

Winch [1958] reopened the issue of the subject matter and methods of social sciences. He rejects the received wisdom that social sciences are still in their infancy and must follow the methods of the natural sciences in order to make progress. He considers social sciences in general, disregarding the differences between particular kinds of social study,

2 Uyezd - sometimes translated as circle, provincial district - an administrative subdivision in Imperial Russia. Several communes constituted a volost (district), several volosts formed an uyezd, and several uyezds formed a guberniya (governorate). 
such as sociology, political theory, and economics because these differences do not affect his argument, which will be outlined in this section without going into the details. Winch's objective is to bring out certain features of a study of society - a social study as such, and to show that it has little to gain from emulating natural sciences.

The principal reason for this is the fundamental differences between the subjectmatter of natural sciences and the subject-matter of social studies. The subject-matter of the former is natural phenomena - the properties, causes and effects of particular objects and processes in the natural world; the subject-matter of the latter is social phenomena. The question about the properties of social phenomena was a starting point in nascent sociology, with many attempts being made to consider social phenomena by analogy with natural phenomena, so the same methods which were successful in the study of nature can be applied to human society. Winch argues that the central problem of sociology - giving an account of the nature of social phenomena in general - belongs to philosophy rather than science. In fact, he says, "this part of sociology is really misbegotten epistemology [...] because its problems have been largely misconstrued, and therefore mishandled, as a species of scientific problem" [Winch 1958, p. 43]. The central question of philosophy is how any understanding is possible. To answer this question, it is necessary to show the central role which the concept of understanding plays in activities characteristic of human societies; this involves a consideration of the general nature of a human society, and an analysis of the concept of a human society [Winch 1958, pp. 22-23].

Furthermore, social scientists are concerned with human behaviour if and insofar as it is meaningful, i.e. has a meaning, makes sense, has motives and reasons. Winch suggests Wittgenstein's account of what it is to follow a rule as a paradigm of meaningful behaviour in general. Accordingly, "all meaningful behaviour must be social since it can be meaningful only if governed by rules, and rules presuppose a social setting" [Winch 1958, p. 116]. The implications of this argument for social sciences are profound.

First, the conceptions, in terms of which we normally think of social behaviour motives, reasons, purposes, efforts, etc. - are logically incompatible with the conceptions belonging to scientific explanation, such as causes, effects, reactions, functions, forces, prediction. Social behaviour is governed by ideas; it implies an understanding of what one does, hence speaking of it in the same terms as those which were developed for the explanation of the movement of physical bodies means missing out exactly what makes it social behaviour.

Secondly, the same point applies to the analysis of social institutions. Social institutions are often regarded as a proper subject for generalisations, based on empirical observations of the kind in which the natural scientists are engaged. Winch shows such attempts are misguided. Durkheim's first rule of the sociological method - to consider social facts as things - disregards the fundamental differences between the physical world and the social world. When the "things" in question are purely physical, the criteria of what constitutes such a thing are those of the observer. With social "things" that is not so, because "for their being intellectual or social, as opposed to physical, in character depends entirely on their belonging in a certain way to a system of ideas or a mode of living" [Winch 1958, p. 108, emphasis in the original]. Social institutions are not just explanatory models introduced by social scientists for their own purposes: the ways of thinking embodied in institutions govern the way the members of the societies studied by the social scientist behave, and any study of social institutions presupposes familiarity with those [Winch 1958, pp. 87-91, 127]. Again, the conceptions, according to which we 
normally think of social events are logically incompatible with the concepts belonging to scientific explanation. The former conceptions enter into social life itself and not merely into the observer's description of it [Winch 1958, p. 95].

The thrust of the book is that social relations, that is (as Winch in a rather old-fashion way put it) "a man's social relations with his fellows", fall into the same logical category as relations between ideas. It follows that social relations are an unsuitable subject for broad generalizations and theories of the scientific sort [Winch 1958, p. 133]. Thus, one does not throw much light on the particular form which even the basic "biological" activities such as eating, seeking shelter and reproducing may take in a given society by speaking of them in Malinowski's neo-Marxist terminology as performing "the function" of providing for the satisfaction of basic biological needs [Winch 1958, p. 131]. A more appropriate objective of a social study is the "investigation of human society whose very nature is to consist in different and competing ways of life, each offering a different account of intelligibility of things" [Winch 1958, p. 103]. In effect, understanding social activities is akin to understanding what is said in a particular language. To understand a conversation in Chinese one needs to learn Chinese rather than formulate statistical laws about likely occurrence of various words in it [Winch 1958, p. 115].

\section{Common-sense and scientific interpretations of human action}

Alfred Schutz addressed the same issues on more familiar territory. Schutz's critique of Talcott Parsons' major work "The Structure of Social Action" unearthed the main fault lines of the, to date, most comprehensive attempt to build a general sociological theory on the same foundations as theories in natural sciences. The main problem was the conceptualisation of the subjective point of view of the actor in the action frame of reference; disagreements between Parsons and Schutz proved to be insurmountable [Davydova 2002].

Schutz strongly believed in the need for social sciences to follow methods of natural sciences. His main concern, however, was that the "the common-sense world", which is the arena of social action and which is given to us in an organised fashion, is usually taken for granted. Schutz shows that the common-sense world is a reality constructed by means of what he calls "common-sense constructs" - abstractions, generalisations, formalisations and idealisations in terms of which we perceive and act upon the world in everyday life. All interpretations of the world of daily life are based on the stock of previous experiences of it, either our own or passed down to us, which functions as a scheme of reference [Schutz (1) 1971, p. 7]. Yet this is not a private world - the world of everyday life is an intersubjective world of culture because in it we are bound to others through understanding others and being understood by them; this world is "a texture of meaning" which we have to interpret in order to find our bearings in it [Schutz (1) 1971, p. 10].

By contrast, the system of relevancies governing scientific work originates in a scientific situation. Any scientific problem is determined by the actual state of the respective science, and its solution must be achieved in accordance with the procedural rules governing this science, including the possibility of controlled verification of any offered solution. The scientific problem alone determines what is relevant for the scientist 
as well as the conceptual frame of reference to be used [Schutz (2) 1971, p. 63]. Schutz argues that the constructs of social sciences - the concepts and theories purporting to explain the social world - are constructs of the second degree, i.e. "constructs of the constructs made by the actors on the social scene, whose behaviour the social scientist has to observe and to explain in accordance with the procedural rules of his science" [Schutz (2) 1971, p. 59].

\section{The methodological implications of Winch's and Schutz's positions}

This brings to the fore the question of the usefulness of specifically sociological concepts and theories - those which are not taken from the activity under investigation but come from the context of the investigation. Schutz himself considered the fundamental insight that sociological concepts are constructs of the second degree to be not a problem but an answer [Schutz (2) 1971, pp. 62-63]. The vital question of the methodology of social sciences is how is it possible to formulate objective concepts and an objectively verifiable theory of the subjective meaning-structures. For Schutz, the solution consists in following certain principles (postulates). Basically, the scientific model of human action must be logically consistent, attribute only typical motives to the actor, and be understandable for the lay members of the society. Compliance with these postulates guarantees both the objective validity of the theoretical constructions designed by social scientists and their compatibility with constructs of everyday life [Schutz (1) 1971, pp. 43-44].

Schutz's advice, intended to ensure that social scientists' theoretical constructions remain consistent with common sense, might work relatively well in economics, but less so in the case of social sciences dealing with social behaviour which is further from the model of rational behaviour. Thus, Schutz's postulates do not resolve the chronic problems of the conceptualisation of morality in sociology. Concept and theory formation in social sciences, as envisaged by Schutz, presupposes a conformity concept of morality which was criticised by Bauman [Bauman 1989] for being an unrealistic and a morally wrong way of considering moral behaviour [Davydova, Sharrock 2003].

Winch's position is more radical and more consistent. Winch questions the very possibility of purely factual descriptions of social life and of a science aiming at explaining "social facts" as "things". Instead, he notes four implications. First, the "technical" concepts of the social scientist imply a previous understanding of the concepts which belong to the activities under investigation [Winch 1958, p. 89]. Secondly, strict logical criteria are justified in evaluating alternative sociological theories but not in considering the ideas and theories which belong to the subject-matter of the study because that means taking sides - the very opposite of the idea of uncommitted (i.e. disinterested) enquiry [Winch 1958, pp. 101-103]. For example, to try to understand a tribe's magical rites by reference to the aims and nature of scientific activity, as a form of misplaced scientific activity, is to misunderstand those [Winch 1958, p. 100]. It seems, what Winch means here is that the social scientist's work must be akin to the work of the interpreter, whose job is to translate as accurately as possible what is being said, not to pass judgements about the content of the conversation or the speakers. Thirdly, although it may be sometimes useful to adopt devices like Weber's "externalisation", it would be a mistake to think that this way of looking at things is somehow more real 
than the usual way [Winch 1958, p. 118]. Fourthly, the very notion of intelligibility is systematically ambiguous, i.e. its sense varies systematically according to the particular context in which it is being used [Winch 1958, p. 18].

If sociological theories play only a subsidiary role, their choice must be pragmatic. This is the view taken in this study of the practices of mutual assistance among Russian peasantry and of their evolution in the twentieth century. The theories in terms of which these practices are considered have been chosen because they draw attention to certain features of mutual assistance amongst peasants or to certain aspects of peasant life. The objective is neither to subscribe to any particular theory nor to design one's own "theory of mutual assistance"; it is rather to understand what mutual assistance consisted of, how it fitted in with the rest of peasant life, how it changed, and why. Winch and Schutz show that any knowledge, any information, is socially constructed rather than simply given. This directs attention to what is considered to be "data" in a sociological study, necessitating careful yet critical handling of the sources. This also means (pace Schutz) that any conclusions drawn from such a study can only be tentative and relative.

\section{The diversity of practices of pomochi}

The aim of the ethnographic surveys, materials of which are extensively used in this study, was to collect detailed and accurate information about various aspects of Russian peasant life, gathered by close observers. The correspondents of Tenishev's Bureau were required (just as today's contributors to Wikipedia are) to convey facts rather than their own generalisations and conclusions. However, some biases were inevitable: i) the selfselection bias (i.e. only people with views sympathetic to the programme were likely to agree to become a correspondent); ii) the uneven distribution of education and literacy in the population determined the size of the network of potential correspondents, which affected the territorial representativeness of the information collected; iii) familiarity with various aspects of peasant life varied from correspondent to correspondent; iv) the stylistic editing of the received accounts by the Bureau [Firsov, Kiseleva 1993, pp. 12-14]. The ethnographic materials should not be regarded as first-hand accounts of the practices by their participants, but nowadays these materials are the best systematic accounts available.

The noun pomochi is derived from the verb pomoch, which means 'to help'. In grammatical terms the word is plural in form but can also be used to designate a singular occasion of help (although this is subject to regional variation - in some areas a singular form, pomoch, exists). Vladimir Dal in his Explanatory Dictionary of the Living Great Russian Language recorded the word pomochi as common in the northern and eastern parts of the Russian Empire, with the equivalent term toloka used in the south, west, Tver and Novgorod regions [Dal 1882]. In addition, there were many specific terms denoting pomochi for particular kinds of work: dozhinki (dozhiny), vyzhinki, otzhinki, boroda, borodnye, kasha, salamata meant pomochi to complete reaping; navoznitsa to muck out, transport and spread manure in the field; pochebit'e - to make a mud stove; $v z d y m k i$ - to erect the timber frame of a house; kapustki - to harvest and process cabbage into sauerkraut; polotushki - to weed fields or kitchen gardens; senovnitsy - to make hay; drovianitsy - to gather firewood for winter; supryadki,- to spin yarn together; kopotikhi - to wash flax [Gromyko 1986, pp. 38, 55, 56, 57]. 
Fundamentally, pomochi was the custom of collective assistance in peasant communities, encompassing a wide range of practices. On those occasions when pomochi were organised by the decision of the village assembly ( $k$ kod), participation was mandatory and not necessarily rewarded with meal. Such pomochi were typically called to help a family in misfortune, the infirm, the old, widows, orphans [Gromyko 1986, pp. 59-60]. Thus, fire-sufferers could rely on their fellow-villagers for help: the village community would provide timber from the communal forest as well as labour for construction - completely free of charge or to be repaid later in money to the communal fund or in kind by giving a party [Gromyko 1986, pp. 31, 59]. Those who lost their working horse would be assisted with transporting firewood from the forest [Gromyko 1986, p. 59]. Evidence from the 1879 Moscow governorate describes how villagers after the death of both parents in one family took pity on the orphans and farmed the orphans' land on their behalf until they had come of age [Tikhonitskaya 1934, p. 76].

On those occasions when pomochi were organised directly by a family in need, participation was voluntary and reward was never monetary but a good party. The absence of formal payment and the fusion of work and enjoyment were important for the participants. Evidence from the Tobolsk region in 1810 states that, "people readily help each other and this is called pomoch [...]. Festivities afterwards involve singing and dancing to the accompaniment of balalaika or violin [...] working for money on such occasions is considered reprehensible and nobody would agree to do pomoch for money' [Gromyko 1975, p. 78]. Another typical entertainment at pomochi was taking girls and young women for a ride in carts driven by horses. Pomochi at harvest time, in house construction, and in spreading manure in the field sometimes involved rites marking the relevant occasion [Gromyko 1986, pp. 48-53, 55; Tikhonitskaya 1934, pp. 82-86].

Pomochi were called by the rich and by the poor [Gromyko 1986, p. 33]. The lavishness of the entertainment provided by the benefiting family depended on their circumstances. In Belarusian Polesia the feast was expected only if help was by invitation from the landowner, the priest, or a volost clerk; otherwise talaka (i.e. toloka), as with any other help among peasants, went without special treats and quite often major works were done collectively for one just for verbal thanks at the end [Gromyko 1986, p. 38].

A specific type was krugovye pomochi (literally "the round pomochi"), also called poocherednye ("pomochi in turn") [Gromyko 1986, p. 37], or otrabotka (working off) [Tikhonitskaya 1934, p. 78]. At round pomochi several households worked together for each other, often without any treat at the end but each benefiting from the greater number of hands put to work when time was of the essence. Such pomochi often involved relations and neighbours rather than the entire village. Participation was voluntary but with understanding that everyone entering such an arrangement would work for each other until work is done. Round pomochi were often called for scutching flax or hemp which must be urgently processed after being dried out in a barn because it quickly reabsorbs moisture [Gromyko 1986, p. 53]. For the same reason the threshing of sheaves was also often done by round pomochi. Round pomochi for mucking out, transporting and spreading manure in the fields would often engage the entire village, including children as young as 6 or 7 years old. The occasion involved plentiful food, jokes and laughter, and in spite of unpleasantness the work was viewed as fun [Gromyko 1986, p. 54]. A subtype of otrabotka was supryaga (co-harnessing), common in Ukraine and Belarus, where households, each with an insufficient number of the draught animals (at least two pairs of oxen or horses were needed to draw a plough) would club together for 
ploughing their fields. Another reason for supryaga was that not all households owned the complete set of plough parts.

There were many other variations. Sometimes it was mostly young people who participated, as with making a mud stove or processing cabbage into sauerkraut. Pomochi for scutching flax and spinning yarn involved only women. Some pomochi happened on weekends and holidays, others during weekdays, while gatherings for scutching flax or hemp took place in a barn at night. Pomochi to spin yarn could be organised in the round manner, e.g. in Kostroma region gatherings to spin yarn together went on from autumn until Christmas, moving from one house to another [Gromyko 1986, p. 57], but another way was to ask girls and young women to take wool, flax, or hemp home and bring back yarn on an agreed day when they would be treated to dinner by the housewife for whom they did the work. The length of the workday at pomochi also varied. Usually as many helpers were invited as it was necessary in order to finish job by the evening, but in the Tver, Vladimir, and Simbirsk regions the custom was to work at pomochi only until midday [Gromyko 1986, p. 34]. Some pomochi ended with a party for the entire village (even if not everyone participated in the work), and some - such as for spinning yarn, scutching flax or hemp, reaping - only for helpers. In the latter case if a helper was allowed to bring to the party one more person such an extra was called zakhrebetnik ('parasite') [Gromyko 1986, p. 52]).

Therefore, the practices of pomochi varied in respect of:

1) who organised help (the village assembly, or an individual family, or a number of families);

2) who was invited to provide help (all villagers, or only relations and neighbours, or the young, or women);

3) to whom food and entertainment were provided in gratitude (to the entire village, or to helpers, or none at all);

4) whether food was provided only after the work or during the work as well;

5) when and for how long work went on (on holidays, or weekdays, until midday, or all day, or at night, or in the evening throughout a period of time;

6) whether work was done collectively in one place or individually at home by helpers;

7) whether any rites were performed or not.

The practices differed between localities, but also often in the same locality there was more than one way of doing "pomochi". Yet all these practices are sufficiently similar to recognise them as essentially the same custom, the common traits of which were informality, the mobilisation of the collective to help a community member, the free nature of the help, and fun as its accompaniment.

\section{The custom of pomochi in the light of the social science concepts}

\section{A form of reciprocity}

A modern reader might question the free nature of help given at pomochi, asking: "But was there not an expectation of quid pro quo? Did not participants expect to be assisted 
in doing their work in the same fashion? If this was the case, then payment might have not been monetary, but the help was not free at all." This kind of question derives from the understanding of help typical of our own present-day culture, and, perhaps, is also informed by the theories of reciprocity.

Sahlins introduced an influential formal typology of reciprocities: i) generalised reciprocity - "transactions [...] of assistance given and, if possible and necessary, returned"; ii) balanced reciprocity - direct exchange in which "the reciprocation is the customary equivalent of the thing received and is without delay"; iii) negative reciprocity the "the attempt to get something for nothing with impunity" [Sahlins 1972, pp. 194-195]. This typology emphasises the underlying self-interestedness of gift giving, sharing, hospitality, help and generosity. Under such a definition pomochi is a case of generalised reciprocity, with round pomochi perhaps fitting better the category of balanced reciprocity. However, to recast pomochi in terms of these concepts of reciprocity is to change the description of the practice. The new description substitutes social science concepts (constructs of the second degree) for the participants' concepts which were integral part of the practice.

From the point of view of the participants, work on the occasions of pomochi was gratuitous, viewed as, as "a labour of respect" (iz uvazhenia) given for free (darovaya). People worked "rather because it does them honour to help a man" (rabotaiut skoree $i z$-za chesti, chtoby pomoch' cheloveku). Meals, associated with pomochi, especially if provided during the work, were generally viewed not as payment but an expression of gratitude as well as a matter of convenience [Gromyko 1986, p. 60]. Providing lunch ensured that afterwards all helpers were able to resume work at the same time [Tikhonitskaya 1934, p. 82]. Refusals to attend pomochi, being a snub to the inviter, were rare. Able-bodied people who received help from others were expected to help them in future: "if one had organised pomoch, then he himself or someone from his family ought to attend pomochi called by his helpers; only a good reason can relieve him from such an obligation" [Gromyko 1986, p. 61]. In some places, however, the obligation to reciprocate was weaker if one gave a party after the pomochi [Gromyko 1986, p. 61].

As far as the practice participants were concerned, help at pomochi was "free" and yet entailed expectations of help in return. For them there was no contradiction in this because their view of "free" help differed from our modern understanding of the matter cast in terms of altruism versus self-interestedness. For peasants help obliged; this idea was interwoven with their other ideas and practices; the same could be said about us. This, ultimately, is the difference between their way of life and ours.

To conclude, practices of pomochi were based on reciprocity, but it was a very different form of exchange to market exchange based on pre-agreed payment for goods and services. Only with the round pomochi was there a specific expectation of help in return. For the most part, the participants' "reward" consisted in the enjoyment of the social occasion, with a general understanding that one would also be helped in the future if in need. The obligation to help in return was moral rather than contractual. Lone elderly people, widows, the infirm were helped even though they would never be able to 'repay' in a quid pro quo manner. 


\section{A form of communal farming}

The vast ethnographic surveys confirm the ancient origin and wide geographical spread of pomochi in Imperial Russia. The very word toloka also meant commons - publicly owned pastures - strongly suggesting links with a more ancient communal farming system [Gromyko 1986, p. 36]. Round pomochi in particular appear to be a relic of earlier times when land was farmed collectively by the village community. Evidence from Solvychegodsk region in 1879 describes how on those occasions when the slashand-burn system was used to bring new land into cultivation the community did all the work together - clearing the forest, ploughing, sowing (each bringing an equal share of seeds), reaping, threshing - and then shared grain, straw, and other by-products of threshing equally [Tikhonitskaya 1934, p. 75]. If a collective effort was needed to drain meadows, as in Olonets region, then hay-making was also done collectively and haycocks were shared equally between the participants. Under such arrangements people agreed to equal participation in collective work in order to receive equal shares of the return. Yet if a participant unexpectedly fell ill at the time of hay-making he still received an equal share of hay. Similarly, in Orlov and Vyatka regions meadows often remained in collective use due to difficulties with dividing them into equitable plots for individual use [Tikhonitskaya 1934, p. 75]. In Siberia - region settled by farmers relatively late and amid great hardships due to the climate and remoteness - the earlier collective forms of farming revived. In the Tyumen region in 1880s old people still remembered how in the past when "all land was free" (volnaya) harvesting bread-grain was always done collectively, by pomoch involving the entire village, which moved from one field to another until harvest was brought in, each family brought their own dinner to the field rather than being treated to meal by the family at whose field harvesting happened to be going on that day [Gromyko 1986, p. 37].

As with the Russian peasant commune, there is a tendency to idealise the custom of pomochi. Take, for example, the Encyclopaedia of Russian People, which defines pomochi as "collective unpaid work among peasants, which was free in character and often took the form of a genuine ritual celebration. Pomochi reflected the Russian peasants' traditional sense of mutual assistance on the basis of mutuality, without exploitation of one peasant by another" [Platonov 2006, p. 718]. The fault in this definition lies in the overworked emphasis on the nationality, spiritual tradition, and benevolence as the basis of the custom. In fact, the custom was not specifically Russian: pomochi were common among Belarussian and Ukrainian peasantry; the term toloka has also existed in Bulgarian, Polish, Slovincian, Suomi, and Croat [Tikhonitskaya 1934, p. 73]; the entry for the term toloka in the early twentieth century Encyclopaedic Dictionary mentions such practices among the Bulgarian, Chechen and Ingush populations, and the Jewish diaspora in the Caucasian Mountains [Brockhauz, Efron 1901, p. 439]. Rites performed at some pomochi were associated with certain occasions - harvest, spreading manure in the fields, construction of a new house rather than with pomochi (collective way of doing these jobs) per se. Good will was important for the custom to exist but so was economic need. The most archaic type of pomochi - collective farming - survived to the end of the nineteenth century only in the regions where it made economic sense. Moreover, peasants were interdependent in their farming because of the common ownership of land by the commune. Fields 
were divided into strips farmed by individual families, so someone's delay may lead to delays for others, e.g. everyone had to finish reaping before fencing could be removed in order to let cattle graze in the field [Tikhonitskaya 1934, p. 76].

A similar, albeit lesser bias can be found in works by Gromyko, which generally are exemplary thorough and have been extensively quoted in this paper [Gromyko 1975; Gromyko 1986; Gromyko 1991]. Gromyko distinguishes between three forms of the custom: i) round pomochi, ii) pomochi by decision of the village assembly, iii) pomoch $i$ organised by an individual family [Gromyko 1986, p. 27], and offers many rich accounts of the practices. However, the issue of inequality between peasants and of the effect this had on the practices of mutual assistance are glossed over, and an overemphasis on the moral norms is also detectable, especially in later works [Gromyko 1991, p. 40].

\section{A form of production cooperation}

A rather different view on pomochi is presented in an article reporting evidence collected by its author in Vyatka region in 1927-8 [Tikhonitskaya 1934]. The author applies Marx's theory of cooperation to make a case for pomochi (toloka) being a form of production cooperation which is based on the common ownership of the means of production (land), and is typical of the peasant commune [Tikhonitskaya 1934, p. 73]). The forms of pomochi are classified into types by reference to two principles: i) the land-use system and ii) legal relations between the participants. Accordingly, there are: 1) an archaic system of collective farming; 2) toloka based on common ownership of land but individual land-use; the latter type is subdivided into: 2.1) charitable toloka to help the disadvantaged; 2.2) toloka rewarded with a feast; 2.3) toloka based on an agreement between individual families to mutually assist each other (otrabotka - round pomochi) [Tikhonitskaya 1934, p. 80].

Tikhonitskaya's analysis of the sources produces significant evidence of exploitation associated with toloka. First, there were also toloka organised to benefit landlords, clergy, and representatives of the authorities. In Ukraine certain holidays during which peasants were routinely asked to work at toloka to benefit their local priest or church were known as "priest's holidays" (popivski prazdniki) [Tikhonitskaya 1934, p. 77]. Secondly, the better off were in position to benefit more from the custom because they could better afford food to treat their helpers. Thirdly, the charitable toloka was in decline in villages with acute inequality [Tikhonitskaya 1934, p. 76]. Fourthly, the terms of supryaga, allowed a return on capital in addition to return on actual labour of its participants. Under supryaga arrangements the participants worked on each other's fields in turn but not necessarily for an equal amount of time. A ploughman was entitled to a greater part of the collective pool of work-time than a drover, and a plough or a drought animal entitled its owner to the same share as a ploughman - in addition to the share earned by the owner's actual labour [Tikhonitskaya 1934, p. 79]. Therefore the better off partners were able to use the labour of the poor in the form of "working off rent" - extra work-time the poor had to give to have access to draught animals and plough parts which they themselves were lacking. By the late nineteenth century this kind of arrangement was very common in areas where land was cultivated by plough [Tikhonitskaya 1934, p. 79]. 
Apart from the ideological bias, such differences of opinion are due to the diversity of evidence generated when rural Russia was undergoing radical transformation, which accelerated at the beginning of the twentieth century. In words of Chayanov, favourable changes for agriculture in the global market, the emergence of the domestic market for agricultural products due to development of industry, the rapid development of market relations, the increasing marketability of peasant farms, the fast expansion of trade, the unstoppable advancement of the cooperative movement, the steady growth of societies for the encouragement of agriculture and especially of organisations providing agronomic support to peasants - all these developments - had such an accumulative effect that by 1914 the Russian village "little resembled itself of the previous century" [Chayanov 1967, p. 6].

\section{A substitute for hiring labour}

Practices of pomochi were closely related to the peasant commune but were also rooted in the peasant domestic mode of production. Chayanov in his theory of the peasant economy emphasised the absence of the institution of hired labour as its key feature. The subject of his analysis is a family which farms without using hired labour, has at its disposal a relatively small acreage and capital, only occasionally resorts to nonagricultural earnings, and has limited relations with the market. Such a family farm is not a capitalist enterprise of classical economics. In Russia $90 \%$ of all farms at that period were family farms in this strict definition of the term [Chayanov 1967, p. 72].

When a family farm is a proper capitalist enterprise as, for example, in southern Germany, the correlation between the size of the family and scale of the business is weak or absent: family members excessive to the needs of the farm leave the farm, and if labour is needed hands are hired [Chayanov 1967, p. 33]. In Russia the size and composition of the peasant family (typically, multi-generational at that time) set both maximal and minimal limits to its economic activities: the maximum amount of work physically possible for the family members to deliver, and the minimal level of consumption necessary for survival. Correspondingly, the scale of economic activities of the family changed throughout the natural course of the family's life [Chayanov 1967, pp. 20, 27-29, 33, 62]. Moreover, the greater the mouths/earners ratio, the more work (both at the farm and other earnings) done by each earner [Chayanov 1967, p. 42]. Generally, the peasant family strived to reach a balance between its needs and its work - "the labour-consumer balance" - defined as the meeting point between the marginal drudgery of work generating the family's earnings and the marginal value of the family's consumption [Chayanov 1967, p. 46].

Most relevant for our purposes here is absence of wages as an accounting category on the peasant family farm. Labour was valued not in monetary terms, but in subjective terms: its perceived drudgery measured against the necessity to satisfy the family's needs. Seen from this economic perspective, mutual collective assistance in the form of pomochi was an alternative to hiring labour on occasions when the family did not have enough hands for the job. Other relevant factors were the limited relations with the market and the high level of self-sufficiency - most food consumed by the peasant family was produced on the family farm. It was both necessary and convenient to ask for 
help in certain situations, to be helpful in turn, to help with one's own labour rather than money, and to thank helpers with food, a great part of which would be home-produced. That pomochi were an alternative to hiring labour is well explained by an observer from Siberia, who in 1848 wrote that "pomoch is organised in order to - in one go, while weather is fine - cut all grass in the meadow, reap bread-grain in the field, etc., which relieves one of the hassle of hiring workers and the need to supervise them, it saves time and limits one's expenses to the cost of food consisting of cold snacks at lunch and dinner in the evening" [Gromyko 1975, p. 78].

However, despite pomochi's economic functionality, its social aspect was a fundamental part of the custom. A respondent from Siberia wrote to the Geographical Society in 1850 that the "processing of cabbage, which marks the completion of field work, is joyful for the young: kapustki start the village parties, the village balls so to speak; it is a rare family with even one daughter of marriageable age, which would make sauerkraut themselves [...], they all invite young people of both genders to come in the morning to take part' [Gromyko 1975, p. 79].

\section{The evolution of the practices of mutual assistance in the course of modernisation}

The role of the practices of mutual assistance in the peasant economy explains their rapid decline in the twentieth century. Here, first, changes due to the advancement of capitalism, and secondly, changes due to collectivisation will be considered.

\section{Changes due to the monetisation of the rural economy}

The practices of pomochi were eroded by the monetisation of the Russian rural economy, brought about by the development of capitalism. In 1894, the author of Olonetsky pomochi was already lamenting the decline of 'this wonderful ancient custom', conveying reports that rewarding with a feast was being replaced by payment of money in places located near main roads and towns, meaning the participants of such help were becoming just hired hands [Kulikovsky 1894, p. 396]. In 1898 a correspondent from Vologodsky region noted that pomochi were becoming more expensive than hired labour because one had to thank the participants with costly treats [Gromyko 1986, p. 59]. Thus, pomochi were disappearing through their direct replacement by hired labour. Prosperous peasants (as well as priests and gentry) were the first to switch to hiring labour instead of organising pomochi, precisely for the reason cited above [Tikhonitskaya 1934, pp. 77-78]. This was a shift from traditional reciprocity embedded in long-term relationships within the village community towards the modern type of exchange based on immediate payment for goods and services - by those who can afford it.

Some forms of pomochi, e.g. for spinning yarn (supryadki), easily mutated into low wage employment for the village poor by their better off neighbours. A woman born in 1908 recalls how in her youth she worked hard - "day and night" - "spinning wool for other people", and the money she earned in this way over the winter only sufficed to buy 
new boots and galoshes [Berdinsky 2011, p. 43]. For her there is no question here that she was cheap labour, pomochi is not even mentioned. But for us, the outside observers, there is a clear parallel between her story and descriptions of supryadki collected by ethnographers in the earlier period: usually supryadki were organised by women from households which lacked female hands for the job (consisting mostly of men or with too many children etc.); after sending off raw materials sufficient time was allowed for making yarn; on a certain day helpers in their best dresses brought back yarn and were treated to a dinner with singing and dancing; in some areas the number of helpers was as high as fifty [Gromyko 1986, p. 57].

Furthermore, greater accountability of individual contributions was introduced into the round pomochi. As mentioned, in the late nineteenth century, supryaga arrangements allotted different shares to different roles in the work process, and allowed for a capital share alongside a share given to the actual physical labour of the participants. According to ethnographic research in 1927-8, Vyatka region, round pomochi (otrabotka) among individual family farms (edinolichnye khozyastva), the participants made sure that there were the same number of people (and horses) from each family working the same amount of time [Tikhonitskaya 1934, pp. 81, 88, 90]. Strict accounting of individual contributions made such round pomochi a kind of business partnership.

The mutual assistance of the past was being replaced by individual arrangements when in exchange for help people were expected to work for free for their benefactors. A woman born in 1911, Saratov region, remembers how, when she was a young girl, her family lost their horse in summer and was helped out with transporting sheaves from the field by their better-off neighbours, but had to return the favour by weeding and reaping for free on the fields of the family which provided this help [Davydova 1999]. Again, such arrangements are closer in spirit to employment (on very unfavourable terms for the poor) than to pomochi. It was these practices which Russian Marxists regarded as a clear indication of the advancement of capitalism in the Russian village, and of the on-going differentiation and proletarianization of the peasantry.

\section{Changes due to collectivisation}

Finally, with the collectivisation of farming in the USSR in 1929-34, households ceased to be the primary production units, which made much of the rationale for pomochi redundant. The effect that this shift had on the practices of mutual assistance was fundamental but unfolded gradually and in a rather complex manner. Pomochi which were directly related to farming disappeared at once. Indeed, these practices were a form of mutual assistance between farming families and so were not required at collective farms. On the other hand, for a long time after collectivisation, subsidiary plots (lichnoe podsobnoe khozyastvo) continued to be a major source of food for villagers and the slow pace of mechanisation of agriculture ensured many continuities in their daily life. The impact of social conflict during collectivisation, of the starvation which followed, of World War II, and of the dramatic post-war changes in the demographic composition of the rural population were immense but lie outside the scope of this paper.

The life-histories from the Saratov region, which are the basis of the following analysis of evolution of rural practices of mutual assistance, were recorded in 1991-2. 
These life-histories depict pomochi as a thing of the past, of a time when the respondents, born before 1917, were children or young adults. The respondents recalled collective assistance for the old, the infirm and widows in the pre-revolution village, but very few of them ever organised pomochi themselves. These were pomochi to assist house construction, keenly remembered as fun occasions. Importantly, their many accounts of instances of help show that after collectivisation help between villagers became individual (i.e. one person helping another) rather than collective (i.e. many helping one) in character.

They also provide plentiful examples of later practices which seem to be transitional forms between the old-style mutual assistance and fully monetised exchanges based on formal agreements, typical of modern economies. Examples of such 'transitional forms' include: craftsmen charging less for their work when the buyer was a relation or a neighbour, especially if poor; terms of lending (of grain primarily) dependent on whether or not the debtor was a relation; a girl taken as a nanny, receiving lodging but no wages; extensive help in the kitchen given to neighbours during wedding and funeral preparations; an old woman routinely baby-sitting for her neighbours who, in turn, look after her.

While the social norms associated with mutual assistance became eroded, their replacement - norms which guide behaviour associated with hiring labour - developed quite slowly. A form of abuse of the retreating custom was inviting people to help with certain chores and then not feeding them, as if the job done was disinterested help. Thus, a woman, born in 1911, recalls how she and her friend spent all day washing cabbage in ice-cold water and then slicing it for another woman in their village, hoping for cabbage soup with chicken pie, but neither lunch nor dinner were offered, and after work was finished the woman "just shouted from the doorstep, 'many thanks' and that was that". Another story from mid 1930s: two women dug someone's kitchen garden, 40 sotkas (0.4 hectares) in total, hoping to earn some money, but again, no payment, no dinner just "thanks". Or the story of a woman who was invited to clean the house but offered no meal, just thanked after a long day's work. A man, born in 1907, tells how he and his father sawed firewood but the fellow for whom they did the job threw them out, refusing to pay on the pretext that wood was sawn into uneven blocks. In all these instances the expectation of reward was informal and so could not be enforced.

Generally, the boundary between help and paid work was blurred at that time because of the rural practice of paying for certain kinds of work with food or drink rather than money. Work done for other people was still not properly paid (no pre-agreed fee), but was not freely given help, as with pomochi, either. This created ambiguities which could be exploited by the greedy. Most of the stories above were told as examples of human greed.

Paradoxically, in parallel to non-payment for work there was the opposite trend at that time: to charge for what one would regard as help between neighbours. Consider a story from 1940s about a woman - the only one in the village to own a sewingmachine - who when asked for help with sewing said, "alright, here, do it yourself" and later "for these three seams - could you believe it?!" brought to the narrator "loads of wool demanding it be spun for her".

All these episodes happened in the context of the household economy and subsidiary plots. That was the area where villagers remained to some extent individual farmers. However, there is little indication of reciprocity in these stories, these are not examples 
of mutual assistance. On the contrary, the impression is that assistance with household chores had become a one-way street: better-off villagers invited others to do some work for them and were either generous or mean when rewarding it.

Most importantly, the subsidiary plots were not independent of the collective farm. The stories about pilfering from the collective farm are numerous. The Saratov region suffered a devastating man-made famine in 1932-3, and even afterwards for a long while collective farmers received for their work so little payment that they had to steal from the collective farm if they were to live. However, what started as necessity in order to survive became routine and then a means to riches. Another story describes a way to live well in the late post-war village: barter home-made vodka for grain pilfered from the collective farm (asking a truck driver for the favour), this grain could be used to feed the household's own livestock which later can be sold at market.

Collectivisation meant the end of the peasant family farms analysed by Chayanov. Consequently, pomochi, which were above all a form of mutual assistance between farming families, lost their reason for existing. Caring for the elderly and infirm - another task which was done in village communities by means of pomochi - was gradually taken over by the state. Mechanisation made easier jobs which in the past had required many hands - such as felling and transporting timber for building a house. Now when in need one had to ask for assistance not the village community, but the individuals with access to the collective farm public resources, such as machinery. This unequal access to public resources and to the people with such access fed corruption and bitter resentment. On the other hand, improvements in the infrastructure in rural areas made the daily life of villagers easier, more on a par with the urban population. Yet pomochi - the fun of collective work and merrymaking afterwards - was much missed by those who had memories of it when the custom finally died out.

\section{Concluding remarks}

This study drew on various sources which together span a period of time from the nineteenth century to the end of the Soviet period. This has allowed us to show how the practices of mutual assistance were once an essential feature of the peasant way of life, and to trace their gradual disintegration as that way of life was itself falling apart.

In particular, the custom of pomochi was of ancient origin, related to the peasant commune, and rooted in the peasant economy. The practices of pomochi were diverse, characterised by informality, the mobilisation of the collective to help a community member, the free nature of the help, and fun as its accompaniment. By the beginning of the twentieth century these practices were already in decline due to the advancement of capitalism, being gradually replaced by hired labour and arrangements which were more individual in character. Round pomochi - the very type which is thought to be closest to the ancient communal farming system - were becoming a kind of business partnership. The village poor in exchange for help were expected to work for free for their benefactors. Some kinds of pomochi evolved into low-wage employment. Finally, collectivisation made pomochi redundant by abolishing family farms altogether. The mechanisation of work and the development of rural infrastructure also meant that the mobilisation of a collective to help out a community member was no longer required. 
The community itself was changing. After collectivisation, assistance between villagers became individual rather than collective: there are many accounts in the life-histories from the Saratov region of one person helping another but none of many helping one.

Meanwhile there was a proliferation of practices which appear to be transitional forms between the old-style mutual assistance and fully monetised exchange based on a formal agreement, characteristic of modern economies. Some of these practices, e.g. a kind of "preferential rates" between relations, can be considered a form of help. Other practices, e.g. taking a girl as a nanny and treating her as a servant without even paying her, just providing lodging, come across as exploitation. The social norms associated with the old forms of mutual assistance were eroding. A form of abuse of the retreating custom was inviting people to 'help' and then not even feeding them, as if the job done was a pure disinterested gift. The boundary between help and paid work was blurred due to the rural practice of paying for work (such as digging a kitchen garden, chopping and piling up wood, occasional cleaning of the house) with food or drink rather than money. Work done for other people was still not properly paid (i.e. there was no pre-agreed fee), but was not freely given assistance, as with pomochi, either. This created ambiguities which were exploited. In parallel, the opposite trend was gaining strength: to charge at once for what one would regard as a matter of help between neighbours.

This study has sought to achieve an understanding of some of the traditions associated with the peasant origin of contemporary Russia's population. And what do these traditions mean today? In the late Soviet period something like pomochi still existed among the urban population. The author of this paper cannot be the only one who asked her friends to help with loading and unloading furniture and other stuff when moving from one flat to another, and treating them to a dinner party after the work was done. In contemporary Russia there are reports about ecological activities, at which volunteers, who have come to clean local woods, water reservoirs and rivers from litter, to plant trees, etc. - are treated to meal and entertainment [Tsarev 2014; Sergeev 2013; Dorotova 2012; Nazarenko 2011; Novosibirsky park oberegayut ot musora 2010; Bykova 2009]. Perhaps, it is not too far-stretched to view these arrangements as a distant descendant of the practices of pomochi.

\section{References}

Aksakov K. (1989) Kratkij istoricheskij ocherk zemskikh soborov. Poln. sobr. soch. Tom 1 [Short History of the Assemblies of Land. Collected Papers. Vol. 1], Moscow.

Bauman Z. (1989) Modernity and the Holocaust, Cambridge: Polity Press.

Berdinskikh V. (2011) Rechi nemykh. Povsednevnaya zhizn' russkogo krest'yanina v XX veke [Tales of the Dumb. Daily Life of Russian Peasants in the Twentieth Century], Moscow: Lomonosov Press.

Brockhaus F.A., Efron I.A. (1901) Entsiklopedicheskij Slovar'. Tom XXXIII [Encyclopaedic Dictionary. Vol. XXXIII], Saint Petersburg.

Bykova Y. (2009) Ekologicheskie piraty [Ecological Pirates]. Sovestskaya Sibir', 28.07.2009. Available at: http://www.sovsibir.ru/news/93132, accessed 31 May 2018.

Chayanov A. (1967) Organizatsiya krest'yanskogo khozyajstva [Theory of Peasant Economy]. Oeuvres Choisies de A.V. Cajanov. Vol 1. S.R. Publishers, Limited Johnson Reprint Corporation, Mouton \&amp; Co. Available at: http://www.runivers.ru/bookreader/book103355/\#page/99/mode/1up, accessed 31 May 2018. 
Dal V. (1882) Tolkovyj slovar'zhivogo velikorusskogo yazyka. Tom 4 [Explanatory Dictionary of the Living Great Russian Language. Vol. 4.], Saint Petersburg-Moscow: M.O. Wolff Press; reprinted 1994, Moscow: TERRA press.

Davydova I., Sharrock W. (2003) The Rise and Fall of the Fall-value Distinction. The Sociological Review, vol. 53, no 3, pp. 357-375.

Davydova I. (1999) Moral Traditions of Rural Communities: A Study of Russian Collectivism. $\mathrm{PhD}$ thesis, Sociology Department, University of Manchester.

Davydova I. (2002) Formirovanie etnometodologii: vlianie T. Parsons i A. Schutz na teoreticheskuiu positsiu H. Garfinkel [Emergence of Ethnomethodology: The Influence of T. Parsons and A. Schutz on H. Garfinkel's Theoretical Position]. Sotsiologicheskij zhurnal, no 1 , pp. $115-128$.

Dorotova D. (2012) Posadi derevo - poluchi fontan [Plant a Tree - Get a Fountain]. Sovestskaya Sibir', 27.10.2012. Available at: http://www.sovsibir.ru/news/125611, accessed 31 May 2018.

Fedotov G. (1938) Pis'ma o russkoj kul'ture. Russkij chelovek [Letters on Russian Culture. Russian Man]. Annales Russes. Vol. III, pp. 239-260. Available at: http://www.odinblago.ru/pisma o rus kult, accessed 31 May 2018.

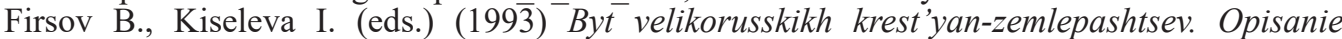
materialov etnograficheskogo buro knyazya V.N. Tenisheva (na primere Vladimirskoj gubernii) [The Way of Life of Great Russian Peasants. Description of Materials Collected by the Ethnographic Bureau of Prince V.N. Tenishev (on Example of the Vladimir Governorate)], Saint Petersburg: Izdatel'stvo Evropejskogo doma.

Gromyko M.M. (1975) Trudovye traditsii russkikh krest'yan Sibiri (XVIII-pervaya polovina $X I X$ veka) [Work Traditions of Russian Peasants in Siberia (Eighteenth - Early Nineteenth Centuries)], Novosibirsk: Nauka.

Gromyko M.M. (1986) Traditsionnye normy povedeniya i formy obshcheniya russkikh krest'yan XIX veka [Traditional Norms of Behaviour and Forms of Social Intercourse of Russian Peasants in the Nineteenth Century], Moscow: Nauka.

Gromyko M.M. (1991) Mir Russkoj derevni [The World of Russian Village], Moscow: Molodaya Gvardya.

Herzen A. (1979) From the Other Shore. The Russian People and Socialism, Oxford: University Press.

Kovalevsky M. (1891) Modern Customs and Ancient Laws of Russia, London.

Kulikovsky G. (1894) Olonetskie pomochi [Olonets Pomochi]. Olonetskij sbornik: Materialy dlya istorii, geografii, statistiki i etnografii Olonetskogo kraya. T. 3 [Olonets Collection: Materials for History, Geography, Statistics and Ethnography of the Olonets Region. Part 3] (ed. Blagoveshchensky I.), Petrozavodsk: Gubernskaya Press, pp. 394-396. Available at: http://oldbook.megacampus.com/files/course/0752_Olonetsky\%20sbornik\%2003.pdf, accessed 31 May 2018.

Nazarenko Y. (2011) Bal proshel i stalo chisto [Ball is Over and Everything has Become Tidy]. Sovestskaya Sibir', 04.10.2011. Available at: http://www.sovsibir.ru/news/115240, accessed 31 May 2018.

Novosibirsky park oberegayut ot musora (2010) [The Novosibirsk Park is Protected from Litter]. Sovestskaya Sibir', 09.09.2010. Available at: http://www.sovsibir.ru/news/107040, accessed 31 May 2018.

Ozhegov S. I., Shvedova N. U. (1992) Tolkovyi slovar'russkogo yazyka [Explanatory Dictionary of the Russian Language]. Moscow: "Yaz'».

Platonov O. (ed.) (2006) Svyataya Rus'. Bol'shaya Entsyklopediya Russkogo Naroda. Russkoe khozyajstvo [Holly Rus. Great Encyclopedia of Russian People. Russian Economy], Moscow: Institut Russkoj tsivilizatsii.

Rybakovsky L. (1981) O migratsii naseleniya v SSSR [On Migration of Population in the USSR]. Sotsiologicheskie issledovaniya, no 4, pp. 7-14.

Sahlins M. (1974) Stone Age Economics, London and New York: Routledge Library Editions, Tavistock Publications.

Schutz A. (1) (1971) Common-Sense and Scientific Interpretation of Human Action. Schutz A. Collected Papers. Vol. 1, Netherlands: Martinus Hijhoff, pp. 3-47. 
Schutz A. (2) (1971) Concept and Theory Formation in The Social Sciences. Schutz A. Collected Papers. Vol. 1, Netherlands: Martinus Hijhoff, pp. 48-66.

Sergeev V. (2013) Podari zhizn' rybe [Give Life to Fish]. Sovestskaya Sibir', 17.05.2013. Available at: http://www.sovsibir.ru/news/132252, accessed 31 May 2018.

Tikhonitskaya N.N. (1934) Sel'skokhozyajstvennaya toloka u russkikh [Agricultural Toloka Among the Russians]. Sovetskaya etnografiya, no 4, pp. 73-90.

Tsarev N. (2014) Chistota territorii - delo kazhdogo [Tidiness of the Area is Everyone's Business]. Sovestskaya Sibir', 18.09.2014. Available at: http://www.sovsibir.ru/news/143960, accessed 31 May 2018.

Vinogradky V. (1998) Krest'yanskie semejnye khroniki [Family Chronicles of Peasants]. Sotsiologicheskij zhurnal, no 1-2, pp. 130-144.

Winch P. (1958) The Idea of Social Science and its Relation to Philosophy, London: Routledge \& Kegan Paul.

\title{
Взаимопомощь среди русских крестьян: практики помочей и их эволюция в процессе модернизации
}

\author{
И.В. ДАВЫДОВА*
}

*Ирина Владимировна Давыдова - кандидат социологических наук, независимый исследователь, работала в НГУ, Манчестерском университете, Ньюкасльском университете. Адрес: Ньюкасл, Великобритания. E-mail: ira.davydova@gmail.com

Цитирование: Davydova I. (2018) Mutual Assistance among Russian Peasants: Practices of Pomochi and Their Evolution in the Course of Modernisation. Mir Rossii, vol. 27, no 3, pp. 107-129. DOI: 10.17323/1811-038X-2018-27-3-107-129

В статье рассматривается эволюция в процессе модернизации практик взаимопомощи среди русских крестьян на примере помочей. Помочи (от глагола «помочь»), или толока, - сбор селян к одному хозяину для дружной работы за угощение или совершенно безвозмездно. Помочи собирались для уборки хлеба, покоса, молотьбы, вывоза навоза на поля, заготовки капусты на зиму, постройки дома и т.д. Крестьяне считали такую работу помощью, а не наймом, а угощение - выражением благодарности со стороны пригласившего, а не платой за свой труд. Помимо исторического интереса, эти практики имеют значение для дискуссий о коллективизме в качестве черты русского национального характера. В исследовании используются различные источники, включая дореволюционные материалы этнографических обследований, этнографическое исследование 1927-1928 гг. и архив семейных хроник, записанных в 1991-1992 гг. в Саратовской области в рамках проекта Т. Шанина.

Методология исследования опирается на работы П. Винча, предложившего витгенштейновский анализ следования правилу в качестве общей парадигмы социального поведения, и работы А. Щюца, анализировавшего различия между 
интерпретацией социального действия в рамках здравого смысла и его научной интерпретацией. П. Винч и А. Щюц подчеркивали логическое различие между социальными понятиями, являющимися интегральной частью исследуемой социальной реальности, и социологическими концепциями, представляющими собой инструменты социологов, сконструированные согласно правилам их академической дисциплины. Данная методологическая позиция определяет роль социологических концепций и теорий как вспомогательную в понимании социальной реальности, их выбор должен быть прагматическим, а в интепретации данных необходима особая деликатность. Практики взаимопомощи рассмотрены (1) в терминах типологии реципротности Салинса, (2) как пережиток более ранней общинной системы земледелия, (3) в рамках марксистского подхода как форма производственной кооперации, (4) в рамках чаяновского анализа организации крестьянского семейного хозяйства. Каждый из этих подходов выявляет определенные черты практик взаимопомощи и крестьянского уклада в целом, помогая понять их эволюцию.

Показано, что помочи были частью крестьянского уклада, а их эволюция следствием его разрушения. Обычай помочей был связан с крестьянской общиной исторически и через взаимозависимость общинников в полевых работах, а также с организацией крестьянского семейного хозяйства, будучи альтернативой наемному труду в работах, требующих большего количества рабочих рук, чем имелось в семье. Обычай охватывал множество практик, общими чертами которых были неформальность, мобилизация коллектива для помощи своему члену, отсутствие оплаты труда и веселье во время работы и угощения. В конце XIX в. эти практики начали приходить в упадок из-за монетизации сельской экономики. Помочи вытеснялись наемным трудом и более индивидуальными по характеру договоренностями. Круговые (поочередные) помочи становились деловым партнерством, а некоторые формы помочей превращались в найм дешевой рабочей силы. Это был сдвиг от традиционной реципрокности, укорененной в долговременных отношениях между селянами, к современному обмену, основанному на немедленной оплате товаров и услуг теми, у кого есть средства. Наконец, коллективизация, упразднив крестьянские семейные хозяйства, сделала помочи невостребованными. Механизация труда и развитие сельской инфраструктуры также означали, что мобилизация коллектива для помощи одному хозяину стала ненужной, и помощь между селянами становится индивидуальной (помощь одного человека другому), а не коллективной (помощь многих одному).

В это же время распространилось множество переходных форм между взаимопомощью прошлого и полностью монетизированным обменом на основе формального соглашения, характерным для современных экономик. Некоторые из этих практик были помощью, другие носили эксплуататорский или коррупционный характер. Социальные нормы, связанные с отжившими формами взаимопомощи, разрушались. Формой злоупотребления старым обычаем было пригласить кого-то «помочь» и потом даже не накормить, как будто проделанная работа была просто подарком. Грань между помощью и наемным трудом была нечеткой из-за деревенского обычая оплачивать вскопку огорода, распил дров, уборку дома и т.п. едой и выпивкой, а не деньгами. Это создавало двусмысленность, которую могли использовать те, кто «нанимал» более бедных селян. Параллельно появилась противоположная тенденция требовать оплаты за то, что, казалось бы, должно считаться обычной услугой между соседями. 
Что осталось от этих традиций сегодня? В поздний советский период среди горожан было принято приглашать друзей помочь с переездом, заканчивающимся застольем на новом месте. В наше время проводятся экологические акции, на которых для участников, пришедших помочь очистить от мусора лес или посадить деревья, организуется питание и развлекательная программа. Возможно, это дальние отголоски когда-то широко распространенного обычая помочей.

Ключевые слова: социологическая теория, социальные понятия, взаимопомощь, помочи, коллективизм, модернизация

\section{Литература}

Аксаков К.С. (1989) Краткий исторический очерк земских соборов. ПСС. Т. 1. М.

Бердинских В.А. (2011) Речи немых. Повседневная жизнь русского крестьянства в XX веке. М.: Ломоносовъ.

Брокгауз Ф.А., Ефрон И.А. (1901) Энциклопедический Словарь. Т. ХХХІІІ. СПб.

Быкова Ю. (2009) Экологические пираты // Советская Сибирь. 28.07.2009 // http://www.sovsibir.ru/news/93132

Виноградский В.Г. (1998) Крестьянские семейные хроники // Социологический журнал. № 1-2. C. 130-144.

Давыдова И.В. (2002) Формирование этнометодологии: влияние Т. Парсонса и А. Шютца на теоретическую позицию Г. Гарфинкеля // Социологический журнал. № 1. C. $115-128$.

Даль В.И. (1882) Толковый словарь живого великорусского языка. Т. 4. СПб.-М.: репринт 1994, Терра пресс.

Доротова Д. (2012) Посади дерево - получи фонтан // Советская Сибирь. 27.10.2012 // http://www.sovsibir.ru/news/125611

Громыко М.М. (1975) Трудовые традиции русских крестьян Сибири (XVIII - первая половина XIX в.). Новосибирск: Наука.

Громыко М.М. (1986) Традиционные нормы поведения и формы общения русских крестьян XIX в. М.: Наука.

Громыко М.М. (1991) Мир русской деревни. М.: Молодая гвардия.

Куликовский Г.И. (1894) Олонецкие помочи // Благовещенский И. (ред.) Олонецкий сборник: Материалы для истории, географии, статистики и этнографии Олонецкого края. Вып. 3. Петрозаводск: Губернская пресса. С. 394-396 // http://oldbook.megacampus.com/files/course/0752_Olonetsky\%20sbornik\%2003.pdf

Назаренко Ю. (2011) Бал прошел и стало чисто // Советская Сибирь. 04.10.2011 // http://www.sovsibir.ru/news/115240

Новосибирский парк оберегают от мусора (2010) // Советская Сибирь. 09.09.2010 // http://www.sovsibir.ru/news/107040

Ожегов С.И., Шведова Н.Ю. (1992) Толковый словарь русского языка. М.: Издательство «Азъ».

Платонов О.А. (ред.) (2006) Святая Русь. Большая Энциклопедия Русского Народа. Русское хозяйство. М.: Институт русской цивилизации.

Рыбаковский Л. (1981) О миграции населения в СССР // Социологические исследования. № 4. C. 7-14.

Сергеев В. (2013) Подари жизнь рыбе // Советская Сибирь. 17.05.2013 // http://www.sovsibir.ru/news/132252

Тихоницкая Н.Н. (1934) Сельскохозяйственная толока у русских // Советская этнография. № 4. C. 73-90. 
Федотов Г.П. (1938) Письма о русской культуре. Русский человек // Русские записки. Т. 3. C. 239-260// http://www.odinblago.ru/pisma_o_rus_kult

Фирсов Б.М., Киселева И.Г. (ред.) (1993) Быт великорусских крестьян-землепашцев. Описание материалов этнографического бюро князя В.Н. Тенишева. На примере Владимирской губернии. СПб.: Изд-во Европейского дома.

Царев Н. (2014) Чистота территорий - дело каждого // Советская Сибирь. 18.09.2014 // http://www.sovsibir.ru/news/143960

Чаянов А.В. (1967) Организация крестьянского хозяйства // Oeuvres Choisies de A.V. Cajanov. Vol 1. Halifax: S.R. Publishers, Limited, Johnson Reprint Corporation, Mouton \& Co // http://www.runivers.ru/bookreader/book103355/\#page/99/mode/1up

Bauman Z. (1989) Modernity and the Holocaust, Cambridge: Polity Press.

Davydova I. (1999) Moral Traditions of Rural Communities: A Study of Russian Collectivism. $\mathrm{PhD}$ thesis, Sociology Department, University of Manchester.

Davydova I., Sharrock W. (2003) The Rise and Fall of the Fall-value Distinction // The Sociological Review, vol. 53, no 3, pp 357-375.

Herzen A. (1979) From the Other Shore. The Russian People and Socialism, Oxford: University Press.

Kovalevsky M. (1891) Modern Customs and Ancient Laws of Russia, London.

Sahlins M. (1974) Stone Age Economics, London and New York: Routledge Library Editions, Tavistock Publications.

Schutz A. (1) (1971) Common-Sense and Scientific Interpretation of Human Action // Schutz A. Collected Papers. Vol. 1, Netherlands: Martinus Hijhoff, pp. 3-47.

Schutz A. (2) (1971) Concept and Theory Formation in The Social Sciences // Schutz A. Collected Papers. Vol. 1, Netherlands: Martinus Hijhoff, pp. 48-66.

Winch P. (1958) The Idea of Social Science and its Relation to Philosophy, London: Routledge \& Kegan Paul. 